\title{
Ethical Climate and Organizational Citizenship Behavior*
}

\author{
Mustafa Fedai Çavuş \\ Associate Professor, Dept. of Management Information Systems \\ Osmaniye Korkut Ata University \\ PO Box 80000, Fakıuşağı Campus, Osmaniye, Turkey \\ E-mail:mfcavus@osmaniye.edu.tr
}

\author{
Alptekin Develi (Corresponding author) \\ Doctoral Student, Institute of Social Science,Osmaniye Korkut Ata University \\ PO Box 80000, Fakıuşağı Campus, Osmaniye, Turkey \\ E-mail: alptekindeveli@gmail.com
}

Received: January 06, 2017 Accepted: February 02, 2017 Published: February 18, 2017

doi:10.5296/ijhrs.v7i1.10561 URL: http://dx.doi.org/10.5296/ijhrs.v7i1.10561

\begin{abstract}
The aim of this study is to determine the effects of ethical climate on organizational citizenship behavior (OCB). This research was conducted on the 200 workers that working in various factories within the Kadirli Organized Industrial Zone. In data collection tool, ethical climate scale of Schwepker (2001) and organizational citizenship behavior scale of Podsakoff (1990) were used. With a five point Likert scale according to the structured questionnaire was included to the research and collected data were analyzed via SPSS.18 statistical analytical software. According to the results of the analysis, ethical climate has significant and positive relationship between sportsmanship, civic virtue and courtesy but, it has not significant relationship between altruism and conscientiousness which are dimensions of organizational citizenship behavior.
\end{abstract}

Keywords: Ethical Climate, Organizational Citizenship Behavior, Kadirli Organized Indisturial Zone, OCB

\footnotetext{
"This research is extended version of the abstract that published in proceedings book belong to 14th National Business Administration Congress on May 7-9 2015, Aksaray, Turkey ISBN: 978-605-9831-01-7
} 


\section{Introduction}

Human resource is the first element to be addressed when designing strategies to make organizations sustainable, both within the rapidly rising local and global competition standards. Because, the primary factor that can move organizations forward by responding to the conditions required by the dynamic business world is the "worker factor", which has materialized all the administrative processes.

In today's work environment in which the effort to achieve superiority is becoming the biggest cost item, more and more need is being given to the approach that implies that volunteers are more willing to fulfill more than the responsibilities defined in the job descriptions of worker, with the concept of organizational citizenship behavior (OCB) in the literature.

Understanding of the psychological atmosphere in the working environment describes the concept of organizational climate. The ethical climate formed by exhibiting correct attitudes and behaviors determines the quality level of the atmosphere. As far as voluntary behaviors are seen in business today, given that responsibilities in the definition of roles can be disturbed, it can be argued that worker' extra-rol behaviors are shaped according to the ethical climate they perceive directly or indirectly.

In this context, the interaction of organizational citizenship behavior representing the whole of voluntary behaviors shown for the benefit of the organization and the ethical climate which expresses the ideal set of values and behaviors has been the subject of research of this study. In this study, an empirical research was conducted to determine the relationship between ethical climate and organizational citizenship behavior.

\section{Ethical Climate}

The concept of ethical climate has been considered by Victor and Cullen (1987) for the first time in an organizational sense, and has become one of the most effective conceptual bases increasingly gaining in importance (Martin and Cullen, 2006). The ethical climate, which includes organizational values, organizational procedures and practices related to ethical attitudes and behaviors, is described by Victor and Cullen as "how ethical problems can be overcome and what is ethically correct behavior" (Victor and Cullen, 1988).

Ethical climate refers to moral values and behaviors that are desired, supported and rewarded within the organization (Schwepker et al., 1997). In other words, the ethical climate is institutionalized organizational practices and processes that demonstrate what is right and what is wrong in organizations, or helps explain what behaviors are acceptable and which are unacceptable (Parboteeah et al., 2005; Büte, 2011).

The ethical climate serves as a map that generates ideas and decisions within the organization and determines the direction in which it will move as it is put into practice (Martin and Cullen, 2006). The ethical climate represents a shared perception of how to deal with problems in the right behavior and moral framework (Parboteeah et al., 2010). Therefore, ethical behavior occurs when members of the organization believe that certain moral 
measures and patterns of behavior exist within the working environment (Cullen et al., 2003).

Formal ethical control systems as well as unethical climate systems are also important (Schminke et al., 2007). Because, in this sense, as even psychologists have perceived perceptions of ethical issues as the most powerful conductors, they argued that individual ethical attitudes have a strong influence on the behavior towards the organization (Cullen et al., 2003).

Ethical climate is the perception of what constitutes correct behavior. This perception creates a psychological mechanism in which moral issues are governed (Martin and Cullen, 2006). Worker can feel the winds of ethics and sense clues and implications of what is right and which is not. This phenomenon, which is not spoken orally among employees, is called an ethical climate (Post et al., 1996; Akbaş, 2010). The power of ethical climate in companies will also affect unity and integrity and morale power (Dickson et al., 2001).

Ethical climate serves organizations in a variety of ways. It guides the employees what they should do when they fall into a moral dilemma (Homans, 1950 as cited in Cullen et al., 2003). In addition, the ethical climate has the opportunity to recognize the ethical issues in the working environment for the worker. In other words, the ethical climate helps make this assessment easier by functioning as a magnifying glass when evaluating people and situations within the organization (Cullen et al., 2003).

Ethical perception of the organization in which the worker is involved is very important in order to increase organizational effectiveness and productivity (Singhapakdi, 1995). In addition, the strong ethical climate in the organizations contributes significantly to the business by increasing the quality of management (Hunt et al., 1989) and firm performance (Wimbush and Shepard, 1994; Weber and Seger, 2002; Verschoor, 1998). The ethical climate also manifests itself by reducing the intention to leave work by increasing levels of job satisfaction (Brown and Peterson, 1993; Schwepker, 2001), organizational commitment (Hunt et al., 1989; Schwepker, 2001) and social responsibility (Singhapakdi et al., 1995; Schwepker, 2001; Elçi ve Alpkan, 2006).

\section{Organizational Citizenship Behavior}

Organizational citizenship behavior has been described by Dennis W. Organ in 1983 as the subject of management and it is defined by the Organ as an effort to demonstrate voluntary effort and extra role behavior beyond the standards and job descriptions set for the individual in the working environment. The concept of volunteering is intended to explain that such behaviors are not the behaviors required by the role of the individual in the organization or the definition of formal work (İşbaşı, 2000).

Organizational citizenship behavior that expresses extra effort beyond the scope of core business responsibilities (Lam et al., 2009); is not a form of reward system and behavior that is not directly or explicitly defined by job descriptions, is not mandatory, is voluntary, and promotes the effective functioning of the organization's functions. The non-mandatory expression in this definition symbolizes that the display of these behaviors is based on personal choice and that no punishment should be applied when it is not fulfilled (Gürbüz, 
2006).

In other words, organizational citizenship behavior refers to, behaviors beyond the formal job descriptions, roles that exceed the specified role requirements and expectations, and manner which the worker are willing to contribute to organization (McDonald, 1993; Schnake and Dumler, 2003; Feather and Rauter, 2004). This concept describes individual behaviors based on volunteerism that contribute to organizational effectiveness and productivity as well as organizational goals in support of the social and psychological environment (Lievens and Anseel, 2004 as cited in Sezgin, 2005).

Organizational citizenship behavior means volunteering to help a colleague who cannot come to work, volunteering to do things that are not officially required by the organization but doing what is important for the organization, helping newcomers to socialize even if they are not part of the job description, helping them overcome difficulties in other workers, working with supervisors or managers, supporting them, proposing new and creative thoughts that will contribute to the organization, participating in more work than necessary, and giving notice when they cannot get to work (Kelloway et al., 2002; Sezgin, 2005).

The behavior of the worker who values effort and creates a peaceful work environment that does not disinterest the tasks assigned to them, and that does not expect it to happen spontaneously, and that feels valued and values the organization, is nothing more than the behavior of organizational citizenship (Çelik, 2007).

\subsection{Dimensions of Organizational Citizenship Behavior}

Organizational citizenship behaviors composed of five-dimensional classification made by Organ; altruism, sportsmanship, conscientiousness, civic virtue and courtesy.

\subsubsection{Altruism}

It refers to all voluntary behaviors that an employee has shown to help other workers who have just begun to work or to help a colleague who has problems with work without anticipation (Organ and Ryan, 1995; Allison et al., 2001).

\subsubsection{Sportsmanship}

With this dimension, avoiding the negative behaviors that may cause tension in the organization, using time efficiently without complaining about the troubles and negativities of the work and other respectful and constructive behavior are explained (Yücel and Samanc1, 2009; Özdevecioğlu, 2003).

\subsubsection{Conscientiousness}

It is the behavior of the members of the organization voluntarily demonstrating the use of time efficiently and in accordance with rules and regulations and beyond the definition of minimum duties. Conduct continuity, regular work and punctuality at the appointment are conscientious behavior (Erşahan, 2011). 


\section{MlMacrothink}

\subsubsection{Civic Virtue (Organizational Participation)}

To take part in organizational meetings regularly and participate actively in discussions, to follow up changes closely and to take active role in accepting others, to benefit from announcement resources, to think about organizational issues, to have knowledge and share it with colleagues are behaviors that can take place in the dimension of civic virtue (Atalay, 2005; Karaman and Aylan, 2012).

\subsubsection{Courtesy}

Having high communication skills is the way to success and coordination for an organization (Samanc1, 2006). The dimension of courtesy is defined as the positive behaviors of individuals who communicate with each other due to their duties in organizations.

\section{Research Method}

\subsection{Sampling}

The sample of the research constitutes 200 workers in Kadirli Organized Indisturial Zone. $113(56.5 \%)$ of the participants were male and 87 (43.5\%) of the participants were female. When we look at the age range of the survey participants, the ones with the ages of 26-35 have the biggest share with $124(62 \%)$ and those with the age of 46 and $6(0.03 \%)$ have the smallest share. When the educational status of the participants is examined, it is seen that most of them have a bachelor's degree with $31.5 \%$, followed by primary school graduates with $28.5 \%$ and high school graduates with $24 \%$. While associate degree graduates have a $15.5 \%$ share, there is only one postgraduate trained worker. When we look at the total working time of the workers, the workers with 2-8 years have the biggest share with 111 people $(55.5 \%)$. In terms of the duration of work in the existing work places, $105(52.5 \%)$ people provide the workers with fewer than two years, followed immediately by $87(43.5 \%)$ and 2-8 years. The demographic characteristics of the participants are shown in Table 1.

Table 1: Demographic Characteristics of the Participants

\begin{tabular}{llll}
\hline Demographic Factors & & Frequency & Percentage \\
\hline \multirow{2}{*}{ Gender } & Male & 113 & 56.5 \\
\cline { 2 - 4 } & Female & 87 & 43.5 \\
\hline \multirow{2}{*}{ Age } & $18-25$ & 32 & 16.0 \\
\cline { 2 - 4 } & $26-35$ & 124 & 62.0 \\
\cline { 2 - 4 } & $36-45$ & 38 & 19.0 \\
\hline
\end{tabular}




\begin{tabular}{|c|c|c|c|}
\hline & $46+$ & 6 & 3.0 \\
\hline \multirow{5}{*}{ Education Status } & Primary School & 57 & 28.5 \\
\hline & High School & 48 & 24.0 \\
\hline & Associate Degree & 31 & 15.5 \\
\hline & Bachelor's Degree & 63 & 31.5 \\
\hline & Post Graduate & 1 & 0.05 \\
\hline \multirow{5}{*}{ Total Working Time } & Less than 2 years & 44 & 22.0 \\
\hline & $2-8$ years & 111 & 55.5 \\
\hline & $9-14$ years & 31 & 15.5 \\
\hline & $15-20$ years & 10 & 5.0 \\
\hline & More than 21 years & 4 & 2.0 \\
\hline \multirow{5}{*}{ Current Working Time } & Less than 2 years & 105 & 52.5 \\
\hline & $2-8$ years & 87 & 43.5 \\
\hline & $9-14$ years & 7 & 3.5 \\
\hline & $15-20$ years & 0 & 0.00 \\
\hline & More than 21 years & 1 & 0.05 \\
\hline
\end{tabular}

\subsection{Scales}

The scale developed by Charles H. Schwepker in order to measure the perceptions of workers towards ethical climate was taken from Biçer's (2005) study. The scale is composed of one dimension (7 items). In order to measure organizational citizenship behavior, the five-dimensional OCB scale developed by Philip M. Podsakoff (1990) was taken from the study of Çağlar (2011). The dimensions of the scale are in the form of altruism (5 items), sportsmanship (5 items), conscientiousness (5 items), civic virtue (4 items) and courtesy (5 items). The scales are evaluated with the Likert scale (1-strictly disagree, 5-strictly agree). 


\section{Findings}

In this study, reliability analysis was performed to measuring the scales' reliability and then correlation analysis and simple linear regression analysis were performed to determine the relationship between ethical climate and organizational citizenship behavior.

\subsection{Reliability Analysis}

The cronbach alpha values were examined to evaluate the internal consistency of the scales. The alpha coefficient of the ethical climate and OCB are shown in Table 2.

Table 2: Reliability Analysis

Ethical Climate $\quad$ OCB

$\begin{array}{lll}\text { Cronbach alpha } \quad .78 & .88 \text {. }\end{array}$

Apart from these the alpha coefficients of five factors of OCB are between .64 and .72. These alpha values indicate the internal consistency of the whole scales.

\subsection{Correlation Analysis}

The analysis of the correlation is shown in Table 3.

Table 3: Correlation Analysis

\begin{tabular}{llllll}
\hline & Altruism & Sportsmanship & Conscientious. & Civic Virtue & Courtesy \\
\hline $\begin{array}{lllll}\text { Ethical } \\
\text { Climate }\end{array}$ &, 028 &, $261^{* *}$ &, 094 &, $189^{* *}$ &, $255^{* *}$ \\
\hline
\end{tabular}

** Correlation is significant at the 0.01 level (2-tailed)

According to the results of correlation analysis, it was found that there were significant and positive relations with ethical climate between sportsmanship $(.261$, **p $<0.01)$, civic virtue $(.189, * * \mathrm{p}<0.01)$ and courtesy $(.255, * * \mathrm{p}<0.01)$ which are the dimensions of organizational citizenship behavior, and it is observed that there is no meaningful relationship with ethical climate between altruism and conscientiousness from the dimensions of organizational citizenship behavior.

\subsection{Regression Analysis}

The analysis of the simple linear regression is shown in Table 4. 
Table 4: Regression Analysis

\begin{tabular}{lllllllllll}
\hline & \multicolumn{1}{l}{ Altruism } & \multicolumn{2}{c}{ Sportsmanship } & Conscientious. & Civic Virtue & \multicolumn{2}{c}{ Courtesy } \\
\hline & Beta & Sign. & Beta & Sign. & Beta & Sign. & Beta & Sign. & Beta & Sign. \\
Ethical &, 028 &, 696 &, 261 &, 000 &, 094 &, 187 &, 189 &, 007 &, 255 &, 000 \\
\cline { 2 - 9 } Climate & $\mathrm{R}^{2}: 001$ & $\mathrm{R}^{2}: 068$ & $\mathrm{R}^{2}: 009$ & $\mathrm{R}^{2}: 036$ & $\mathrm{R}^{2}: 065$ \\
& F: 0.153 & F: 14,470 & F: 1,754 & F: 7,349 & F: 13,717 \\
\hline
\end{tabular}

According to the results of regression analysis, $\mathrm{F}$ value for sportsmanship is significant and it is valid at ,000 level. The $\mathrm{R}^{2}$ ( $\mathrm{R}$ Square) value indicates that the sportsmanship explained $068 \%$ of the model. For civic virtue, the F value is significant, and it is valid at ,007 level. The $\mathrm{R}^{2}$ (R Square) value indicates that civic virtue explains $036 \%$ of the model. For courtesy, the $F$ value is significant, and is valid at ,000 level. The $R^{2}$ ( $R$ Square) value indicates that courtesy explains $065 \%$ of the model.

\section{Discussion}

As a result of various empirical researches conducted with the emergence of ethical climate, it has been found that this concept is also related to other concepts in organizational behavioral literature. These concepts are concepts that significantly affect the organization's success (Carr et al., 2003), such as commitment, job satisfaction and organizational citizenship behavior (Martin and Cullen, 2006).

Organizations in which an ethical atmosphere is not perceived will make it difficult for workers to behave voluntarily (Leung, 2008). This means that it is more likely to see extra role behaviors in work environments where ethical climate is present. The ethical climate will increase the energy of the worker, which will have an impact on organizational citizenship behavior, which is energetically strong.

There are five dimensions of organizational citizenship behavior: altruism, sportsmanship, conscientiousness, civic virtue and courtesy. The analysis of the statistics in the research, it was determined that the ethical climate had no effect on the altruism and conscientiousness from the dimensions of organizational citizenship behavior. Therefore, the ethical climate will be discussed from the dimensions of organizational citizenship behavior to sportsmanship, civic virtue and courtesy.

As a result of the analysis ethical climate shows the effect on organizational citizenship behavior on the sportsmanship dimension at most. The concept of sportsmanship, which is defined as workers' avoidance of behaviors that may cause tension, avoidance of complaints, and display tolerance, will take place as a behavior that is more likely to occur in work environments where ethical climate is present. Sportsmanship behaviors show up itself avoiding growing problems unnecessarily and avoiding disrespectful attitude towards co-workers (Yücel, 2006). As it is understood from this, the sportsmanship behaviors which 
have the features that overlap with the moral principles will be bigger in an ethical climate business environment.

Another effect of ethical climate in relation to organizational citizenship behavior appears on the courtesy dimension. Courtesy is defined as the positive behaviors exhibited by members who are affected by each other's work and decisions, which must be in constant communication with the organization due to their business obligations (Samanc1, 2006). Courtesy behavior in organizations is manifested in the form of consultation with other friends of the business especially about problems (Koys, 2001). Acting on both individual and team-focused relationships, knowing which behavior is right and which behavior is wrong will lead to continuity in both quality and permanence of these relationships. The discrimination of the right and wrong behaviors mentioned above can be achieved through the ethical climate in the organization. Feeling of the ethical climate by the worker will be an incentive to show courtesy-based behavior.

The results of our research show that the ethical climate has the final effect on organizational citizenship behavior on the dimension of civic virtue. Civic virtue, also called organizational participation, means that workers participate actively and responsibly in the management activities of the organization. Attending meetings regularly, observing changes closely, acting in an active role as acknowledged by others, thinking about issues related to the organization, having knowledge and sharing it with colleagues are behaviors that can take place in the dimension of civic virtue (Atalay, 2005). By the features of civic virtues, it is an organizational citizenship behavior that arises from the behaviors of this skill, which should show the loyalty, responsibility and shared approaches of the worker. At this point, ethical climate will enhance the sense of loyalty and awareness of responsibility hereby improve the civic virtue to advanced level.

\section{Conclusion}

The Famous management scientist Peter F. Drucker states "We have known for 50 years that money alone does not motivate employees to perform much more than it motivates volunteers. What motivates volunteers? Volunteers, we know, have to get more satisfaction from their work than paid employees precisely because they do not get a paycheck. They need, above all, challenge" (Drucker, 2014: 29). The relationship of ethical climate and organizational citizenship behavior examined in this study has been exactly corresponding "challenge" expressed in this realistic view, especially in today's business world.

The ethical climate improves attitudes and behaviors of the worker that is to say improves the organizational performance (Elçi and Alpkan, 2009). For example, worker support the development of intra-institutional relationships when they believe that there is an ethical climate within the organization about recruitment, corporate politics, payment system etc. (Weeks et al., 2005 as cited in Lu and Lin, 2014). In order for an ethical climate to be established within institution, ethical rules, institutional policies on ethics, and a system of rewarding and punishment must exist. Because; these factors are the most important factors affecting the attitudes and adaptations of worker regarding ethical rules (Schwepker, 2001). The presence and enforcement of ethical rules will ensure that higher ethical behavior is seen 


\section{Macrothink}

(Ferrel and Skinner, 1988). The existence of ethical institutional policies is also important because it is an opportunity for the worker to show ethical behavior (Bommer et al., 1987). Finally, while the presence of the reward system encourages ethical behavior, the lack of a punishment system will increase the likelihood of unethical behavior (Schwepker et al., 1997).

The ethical climate will create an environment where it is possible to distinguish right behavior from false behavior, which will create a perceptual mechanism that will solve the ethical problems. In this way, unwanted situations such as mobbing and personnel turnover will be reduced, while levels of management quality, job satisfaction and loyalty will be increased (Schwepker, 2001; Cullen et al., 2003). One of the first places where this increase has shown positive effects is organizational citizenship behavior. Worker who perceive to presence personal and institutional ethical values will be directed to show organizational citizenship behavior directly, especially in sportsmanship, civic virtue and courtesy dimensions.

The fact that the ethical climate and organizational citizenship behavior is more informal is impute serious responsibility to top management. These two managerial concepts are up to a locomotive plan to become a corporate culture. Worker will learn correct and voluntary behavior from their superiors by seeing. Therefore, for the improve of ethical climate and the development of organizational citizenship behaviors, superiors must always be one step ahead of subordinate and lead them in this regard.

As a result of the research, it has been seen that ethical climate is influential on sportsmanship, civic virtue and courtesy which are the organizational citizenship behavior dimensions. This suggests that more organizational citizenship behaviors will be seen especially in the organizations where the ethical elements become institutional ethic codes.

In those research conducted by Leung (2008), Butarbutar et al. (2010) and Huang et al. (2012) in which the relationships between ethical climate and organizational citizenship behavior were examined, it is found that ethical climate has increased the individuals' organizational citizenship behaviors. The result of this research also overlaps with the literature in that it suggests that ethical climate is related to sportsmanship, civic virtue and courtesy which are dimensions of organizational citizenship behavior, positively. However, while it is expected that ethical climate will have positive effects on altruism and conscientiousness, no such findings were found as a result of the analysis. This can be brought to the attention of other researchers as a limited aspect of this study.

\section{Acknowledgement}

Thanks for permission to Kadirli Organized Indisturial Zone management, factories and workers where we performed this research. 


\section{References}

Akbaş, T. T. (2010). Örgütsel Etik İklimin Örgütsel Bağl1lık Üzerindeki Etkisi: Mobilya Sanayi Büyük Ölçekli İşletmelerinde Görgül Bir Araştırma. KMÜ Sosyal ve Ekonomik Araştırmalar Dergisi, 12(19), 121-137.

Allison, B. J., Voss, R. S. \& Dryer, S. (2001). Student Classroom and Career Success: The Role of Organizational Citizenship Behavior. Journal of Education for Business, 76(5), 282-289.

Atalay, İ. (2005). Örgütsel Vatandaşlık ve Örgütsel Adalet. Unpublished master's thesis. Afyon Kocatepe University, Afyonkarahisar.

Biçer, M. (2005). Satış Elemanlarının İş Tatmini, Örgüt Bağlılığı ve İşten Ayrılma Niyetinin Etik İklim İle İlişkisi: Sigorta ve İlaç Sektörlerinde Bir Araştırma. Çukurova University, Master's thesis, Adana.

Bommer, M., Gratto, C., Gravander, J. \& Tuttle, M. (1987). A Behavioral Model of Ethical And Unethical Decision Making. Journal of Business Ethics, 6(4), 265-280.

Brown, S. P. \& Peterson, R. A., (1993). Antecedents and Consequences of Sales Person Job Satisfaction. Meta-Analysis and Assessment of Causal Effects. Journal of Marketing Research, 63-77.

Butarbutar, I. D., Sendjaya, S. \& Härtel, C. E. (2010). The Mediating Effects of Ethical Climate on the Relationship Between Servant Leadership and Organizational Citizenship Behavior. In 24th Anzam Conference.

Büte, M. (2011). Etik İklim, Örgütsel Güven Ve Bireysel Performans Arasındaki İlişki. Atatürk Üniversitesi İktisadi ve İdari Bilimler Dergisi, 25(1), 171-192.

Carr, J. Z., Schmidt, A. M., Ford, J. K. \& DeShon, R. P. (2003). Climate Perceptions Matter: A Meta-Analytic Path Analysis Relating Molar Climate, Cognitive and Affective States, and Individual Level Work Outcomes. Journal of Applied Psychology, 88(4), 605-619.

Cullen, J. B., Parboteeah, P. K. \& Victor B., (2003). The Effects of Ethical Climates on Organizational Commitment: A Two-Study Analysis. Journal of Business Ethics, 46, 127-141.

Çağlar, E. (2011). An Integrative Model of Justice Perceptions, Employee Positive Mood States and Organizational Cizitenship Behavior. Master's thesis. Middle East Technical University, Ankara.

Çelik, M. (2007). Örgüt Kültürü ve Örgütsel Vatandaşlık Davranışı-Bir Uygulama. Atatürk University, Unpublished master's thesis, Erzurum.

Dickson, M. W., Smith, D. B., Grojean, M. W. \& Ehrhart, M. (2001). An Organizational Climate Regarding Ethics: The Outcome Of Leader Values and The Practices That Reflect Them. The Leadership Quarterly, 12(2), 197-217. 


\section{I Macrothink}

International Journal of Human Resource Studies ISSN 2162-3058 2017, Vol. 7, No. 1

Drucker, P. F., (2014). 21. Yüzyıl İçin Yönetim Tartışmaları. İstanbul: Epsilon Yayıncılık Hizmetleri, p. 29

Elçi, M. \& Alpkan L. (2006). Etik İklimin Örgütsel Vatandaşlık Davranışlarına Etkileri. Hacettepe Üniversitesi İ̈BF Dergisi. 24(1), 141-170.

Elçi, M. \& Alpkan, L. (2009). The Impact of Perceived Organizational Ethical Climate on Work Satisfaction. Journal of Business Ethics, 84(3), 297-311.

Erşahan, B. (2011). Yönetimde Çağdaş ve Güncel Konular, within Örgütsel Vatandaşlık Davranışı, (pp. 151-171).

Feather, N. T. \& Rauter, K. A. (2004). Organizational Citizenship Behaviors in Relation to Job Status, Job Insecurity, Organizational Commitment and Identification, Job Satisfaction and Work Values. Journal of Occupational and Organizational Psychology, 77, 81-94.

Ferrell, O. C. \& Skinner, S. J. (1988). Ethical Behavior and Bureaucratic Structure in Marketing Research Organizations. Journal of Marketing Research, 103-109.

Gürbüz, S. (2006). Örgütsel Vatandaşlık Davranışı İle Duygusal Bağlılık Arasındaki İlişkilerin Belirlenmesine Yönelik Bir Araştırma, Ekonomik ve Sosyal Araştırmalar Dergisi, $3(2), 48-75$.

Huang, C. C., You, C. S. \& Tsai, M. T. (2012). A Multidimensional Analysis of Ethical Climate, Job Satisfaction, Organizational Commitment, and Organizational Citizenship Behaviors, Nursing Ethics, 19(4), 513-529.

Hunt, S., Wood, V. \& Chonko, L., (1989). Corporate Ethical Values and Organizational Commitment in Marketing. Journal of Marketing 53, 79-90.

İşbaşı, J. Ö. (2000). Çalışanların Yöneticilerine Duydukları Güvenin ve Örgütsel Adalete İlişkin Algılamalarının Örgütsel Vatandaşlık Davranışının Oluşumundaki Rolü: Bir Turizm Örgütünde Uygulama. Unpublished master's thesis, Akdeniz University, Antalya.

Karaman, A. \& Aylan S. (2012). Örgütsel Vatandaşl1k. Kahramanmaraş Sütçü İmam Üniversitesi, IIBFF Dergisi. 2(1), 35-49.

Kelloway, E. K., Loughlin C., Barling J. \& Nault A. (2002). Self-Reported Counterproductive Behaviors and Organizational Citizenship Behaviors: Separate but Related Constructs. International Journal of Selection and Assessment, 10(1-2), 143-151.

Koys, D. J. (2001). The Effects of Employee Satisfaction Organizational Citizenship Behavior, and Turnover on Organizational Effectiveness: A Unit-Level, Longitudinal Study. Personnel Psychology, 54(1), 101-114.

Lam, W., Chen, Z. \& Takeuchi, N. (2009). Perceived Human Resource Management Practices and Intention To Leave Of Employees: The Mediating Role Of Organizational Citizenship Behavior In A Sino-Japanese Joint Venture. The International Journal of Human Resource Management, 20(11), 2250-2270. 


\section{MInstitute ${ }_{\text {Mnk }}^{\text {Macrothin }}$}

International Journal of Human Resource Studies

ISSN 2162-3058

Leung, A. S. (2008). Matching Ethical Work Climate to In-Role and Extra-Role Behaviors In A Collectivist Work Setting. Journal of Business Ethics, 79(1-2), 43-55.

Lu, C. S. \& Lin, C. C. (2014). The Effects of Ethical Leadership and Ethical Climate On Employee Ethical Behavior in The International Port Context. Journal of Business Ethics, 124(2), 209-223.

Martin, K. D. \& Cullen, J. B. (2006). Continuities and Extensions of Ethical Climate Theory: A Meta-Analytic Review. Journal of Business Ethics, 69(2), 175-194.

McDonald, P. R. (1993). Individual-Organizational Value Congruence: Operationalization and Consequents, Unpublished Doctoral Thesis. The University of Western Ontario, Londra/Ontario.

Organ D. W. \& Ryan, K. (1995). A Meta-Analytic Review of Attitudinal and Dispositional Predictors of Organizational Citizenship Behavior. Personnel Psychology, 48(4), 775-803.

Özdevecioğlu, M. (2003). Örgütsel Vatandaşlık Davranışı ve Üniversite Öğrencilerinin Bazı Demografik Özellikleri ve Akademik Başarıları Arasındaki İlişkilerin Belirlenmesine Yönelik Bir Araştırma. Erciyes Üniversitesi İIBF Dergisi, 20(20), 117-135.

Parboteeah, K. P., Cullen, J. B., Victor, B., \& Sakano, T. (2005). National Culture and Ethical Climates: A Comparison of US and Japanese Accounting Firms. MIR, Management International Review, 459-481.

Parboteeah, K. P., Chen, H. C., Lin, Y. T., Chen, I. H., Lee, A. Y., \& Chung, A. (2010). Establishing Organizational Ethical Climates: How Do Managerial Practices Work? Journal of Business Ethics, 97(4), 599-611.

Podsakoff, P. M., MacKenzie, S. B., Moorman, R. H. \& Fetter, R. (1990). Transformational Leader Behaviors and Their Effects On Followers' Trust In Leader, Satisfaction, and Organizational Citizenship Behaviors. The Leadership Quarterly, 1(2), 107-142.

Post, J. E., Frederick, W. C., Lawrence, A. T., \& Weber, J. (1996). Business and Society: Corporate Strategy, Public Policy, Ethics. 7th press, McGraw Hill, Inc., International Edition.

Robinson, S. L. \& Morrison, E. W. (1995). Psychological Contracts and OCB: The Effect of Unfulfilled Obligations on Civic Virtue Behavior. Journal of Organizational Behavior, 16(3), 289-298.

Samancı, S. (2006). Örgütsel İklim Ve Örgütsel Vatandaşlık, Unpublished master's thesis. Afyon Kocatepe University, Ankara.

Schminke, M., Arnaud, A. \& Kuenzi, M. (2007). The Power of Ethical Work Climates. Organizational Dynamics, 36(2), 171-186.

Schnake, M. E. \& Dumler, M. P. (2003). Levels of Measurement and Analysis Issues in Organizational Citizenship Behavior Research. Journal of Occupational and Organizational Psychology, 76, 283-301. 


\section{Macrothink}

International Journal of Human Resource Studies

ISSN 2162-3058

2017, Vol. 7, No. 1

Schwepker, C. H., Ferrell, O. C. \& Ingram, T. N. (1997). The Influence of Ethical Climate and Ethical Conflict on Role Stress in The Sales Force. Journal of the Academy of Marketing Science, 25(2), 99-108.

Schwepker, C. H. (2001). Ethical Climate's Relationship to Job Satisfaction, Organizational Commitment, and Turnover Intention in The Salesforce. Journal of Business Research, 54(1), $39-52$.

Sezgin, F. (2005). Örgütsel Vatandaşlık Davranışları: Kavramsal Bir Çözümleme ve Okul Açısından Bazı Çıkarımlar. Gazi Üniversitesi Eğitim Fakültesi Dergisi, 25(1), 317-339.

Singhapakdi, A., Kraft, K.L., Vitell, S.J. \& Rallapalli, K.C., (1995). The Perceived Importance of Ethics and Social Responsibility on Organizational Effectiveness: A Survey of Marketers, Journal of Academy of Marketing Science, 23(1), 49-56.

Verschoor, C. C., (1998). A Study of The Link Between A Corporation's Financial Performance and Its Commitment to Ethics. Journal of Business Ethics, 17(13), 1509-1516.

Victor, B. \& Cullen J. B., (1988). The Organizational Bases of Ethical Work Climates. Administrative Science Quarterly, 33(1), 101-125.

Weber, J. \& Seger, J.E., (2002). Influences Upon Organizational Ethical Subclimates: A Replication Study of A Single Firm at Two Points in Time. Journal of Business Ethics, 41(1-2), 69-84.

Wimbush, J. C., \& Shepard, J. M. (1994). Toward an Understanding of Ethical Climate: Its Relationship to Ethical Behavior and Supervisory Influence. Journal of Business Ethics, 13(8), 637-647.

Yücel, G. F. (2006). Öğretmenlerde Mesleki Tükenmişlik ve Örgütsel Vatandaşlık Davranışı, Unpublished master's thesis, Afyon Kocatepe University, Afyonkarahisar.

Yücel, C. \& Samanc1, G. (2009). Örgütsel Güven ve Örgütsel Vatandaşlık Davranış1. Fırat Üniversitesi Sosyal Bilimler Dergisi, 19(1), 113-132.

\section{Copyright Disclaimer}

Copyright for this article is retained by the author(s), with first publication rights granted to the journal.

This is an open-access article distributed under the terms and conditions of the Creative Commons Attribution license (http://creativecommons.org/licenses/by/3.0/). 